\title{
Nilai-Nilai Karakter Religius dalam Kegiatan Pencak Silat
}

\author{
Afif Putra Nazwan', Alfurqan² \\ afifputera02@gmail.com ${ }^{1}$, alfurqan@fis.unp.ac.id ${ }^{2}$ \\ Universitas Negeri Padang ${ }^{1,2}$
}

\begin{tabular}{l}
\hline ARTICLE INFO \\
\hline Article history: \\
Received, 10 November \\
2021 \\
Revised, 27 Januari 2022 \\
Accepted, 28 Februari \\
2022 \\
\hline
\end{tabular}

Keywords:

Karakter religius

Pencak silat

ISMD Putra Setia

Conflict of Interest:

None

Funding:

None

\begin{abstract}
This study aims to find out about the values of religious character in the pencak silat activities of ISMD Putra Setia Nagari Sikabu. In this research, the researcher uses field research with a qualitative approach, a qualitative approach is a research method used to examine the condition of natural objects, where the researcher is the key instrument. In this study, the sources or informants were 2 teachers or trainers and 4 students from the ISMD Putra Setia college. Collecting data in this study using observation, interviews, and documentation. From the results of the study it was found that the values of religious character in pencak silat activities among members of the Putra Setia Nagari Sikabu ISMD college, among others: 1) the existence of a disciplined attitude, 2) an honest attitude, 3) a polite attitude, 4) an attitude patient, 5) the attitude of responsibility, and 6) the attitude of hard work.
\end{abstract}

Corresponding Author: Afif Putra Nazwan, Department Islamic Education Faculty of Social Science Universitas Negeri Padang, Indonesia, Email: afifputera02@gmail.com, Phone No: $+6282169777959$

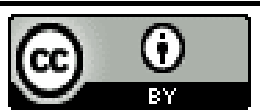

Copyright(C2022, Author(s)

\section{Pendahuluan}

Masyarakat Indonesia telah terbawa ke dalam arus perubahan yang mulai melupakan pendidikan karakter bangsa, hal ini adalah dampak globalisasi. Sedangkan penanaman pendidikan karakter adalah tonggak bangsa yang sangat penting di tanamkan sejak awal, supaya karakter pemuda serta anak- anak terbentuk dengan baik (Huda, 2019: 1). Karena dengan pendidikan karakter ini akan tercipta masyarakat yang religius, tangguh, kompetitif, berakhlak mulia (Ma'ruf, 2019: 1). Menurut Mulyasa pendidikan karakter memiliki makna lebih tinggi dari pendidikan moral, karena pendidikan karakter tidak hanya berkaitan dengan masalah benarsalah, tetapi bagaimana menanamkan kebiasaan (habit) tentang hal-hal yang baik dalam kehidupan (Adyanto et al., 2018: 47).

Sedangkan menurut Irwan Prayitno (2008), secara normatif dan sebagaimana telah hampir dapat diterima oleh umumnya masyarakat, bahwa pembentukan 
karakter bangsa merupakan hal yang amat penting bagi generasi muda dan bahkan menentukan nasib bangsa dimasa yang akan datang (Yuliawan, 2016: 104). Menurut Lickona, suatu karakter dikatakan baik apabila mengetahui akan hal baik, keinginan untuk hal baik, serta mengerjakan hal yang baik, ini nampak dalam kebiasaan berfikir dan bertindak. Teori diatas dapat disimpulkan bahwa karakter adalah tingkah laku yang ditonjolkan melalui kebiasaaan berfikir maupun bertindak (Novita sari et al., 2020: 17). Jadi pembentukan karakter sangat diperlukan untuk membentuk cara berfikir dan cara berperilaku yang ditonjolkan melalui kebiasaan, yang bisa dirubah sesuai keadaan lingkungan, dimana lingkungan sangat berperan sekali dalam pembentukan karakter.

Karakter religius (Islam) menunjukan sebuah sikap induvidu atas kepatuhanya terhadap agama Islam, maka penerapan pendidikan pada sekarang ini sangatlah penting. Penanaman karakter ini sangat penting bagi para generasi muda untuk menghadapi zaman globalisasi dan penurunan kualitas moral, maka dari itu generasi muda di harapkan bisa mempunyai tingkah laku yang baik serta tidak mengerjakna hal- hal yang dilarang dalam agama (Huda, 2019: 4-5).

Olahraga pencak silat sebagai salah satu upaya yang diamanatkan Undang-Undang Republik Indonesia Nomor 20 Tahun 2003. Tentang Sistem Pendidikan Nasional yang pada pasal 3, sebagai berikut: pendidikan nasional berfungsi mengembangkan kemampuan dan membentuk watak serta peradaban bangsa yang bermartabat dalam rangka mencerdaskan kehidupan bangsa, bertujuan untuk berkembangnya potensi peserta didik agar menjadi manusia yang beriman dan bertaqwa kepada Tuhan Yang Maha Esa, berakhlak mulia, sehat, berilmu, cakap, kreatif, mandiri, dan menjadi warga negara yang demokratis serta bertanggung jawab (Undang-Undang No.20: 6) (Novita sari et al., 2020: 17).

Menurut Kriswanto menumbuhkan kepribadian dan karakter mulia seseorang. Pencak silat sebagai aspek mental dan spiritual lebih banyak menitik beratkan kepada pembentukan sikap serta watak yang sesuai dengan falsafah budi pekerti luhur. Maka dari itu pencak silat tidak hanya untuk membentengi diri saja, namun juga mengajarkan untuk lebih mengedepankan kepribadian yang baik sesuai dengan budi pekerti luhur. Sedangkan menurut Notosoejitno dalam Mulyana (2013: 87) pada tataran individu, pencak silat berfungsi membina manusia agar dapat menjadi warga teladan yang mematuhi norma- norma masyarakat. Selain berlatih ilmu beladiri, pencak silat juga melatih untuk hidup bermasyarakat yang berkarakter baik agar menjadi panutan bagi orang disekitarnya (Adyanto et al., 2018: 48). Jadi mempelajari pencak silat bukan hanya untuk perlidungan diri saja, namun di dalam pencak silat juga dalatih dalam pembentukan sikap dan watak kepribadian serta spiritual yang berguna bagi pembentukan karakter yang baik dalam kehidupan bermasyarakat.

Di dalam Negara Indonesia banyak sekali ditemukan berbagai macam perguruan pencak silat yang berkembang, diantaranya terdapat perguruan pencak. Silat ISMD (Ikatan Seni Membela Diri) Putra Setia yang didirikan oleh H. Muhammad Mukhtar Hasfullah di daerah kampung Bulak Klender, Jakarta Timur. Perguruan ini memiliki banyak cabang, salah satunya berada di Nagari Sikabu Kecamatan Lubuk Alung, dan awal berdirinya pada tahun 2012. Yang dibawa oleh pak Ardison dan buk Yeni selaku guru dan pelatih Ikatan Seni Membela Diri Putra Setia di Nagari Sikabu. Dan sesuai dengan namanya, diharapkan anggotanya setia kepada 3 prinsip yakni; kepada Allah, kepada orang tua dan guru, kepada Negara dan bangsa. 
Afif Putra Nazwan Alfurqan: Nilai- Nilai Karakter Religius Dalam Kegiatan Pencak Silat...

Pada zaman sekarang ini di ketahui bahwa kenakalan remaja masih banyak didapati di dalam masyarakat, misalnya minum-minuman keras, berjudi, meniggalkan kewajiban ibadah shalat, ugal-ugalan di jalanan, sehingga pembinaan serta pembentukan karakter bagi remaja sangat penting agar para remaja tidak melakukan perbuatan yang menyimpang. Penelitian ini bertujuan untuk mengetahui nilai- nilai karakter religius dalam kegiatan pencak silat ISMD Putra Setia Nagari Sikabu. Dari latar belakang tersebut penulis tertarik untuk melakukan sebuah penelitian yang berjudul "Nilai- Nilai Karakter Religius dalam Kegiatan Pencak Silat ISMD Putra Setia Nagari Sikabu”.

\section{Tinjauan Pustaka}

Karakter bila ditelusuri asal karakter berasal dari bahasa latin "kharakter", "kharassein", "kharax", dalam bahasa Inggris: character dan dalam bahasa Indonesia "karakter", Yunani character, dari charassein yang berarti membuat tajam, membuat dalam. Dalam kamus Poerwadarminta, karakter diartikan sebagai sebagai tabiat, watak, sifat-sifat kejiwaan, akhlak atau budi pekerti yang membedakan seseorang dengan yang lain. Nama dari jumlah seluruh ciri pribadi yang meliputi hal-hal seperti perilaku, kebiasaan, kesukaan, ketidaksukaan, kemampuan, kecenderungan, potensi, nilai-nilai, dan pola-pola pemikiran (Ainissyifa, 2014: 5). Menurut Pusat Bahasa Depdiknas karakter adalah "bawaan, hati, jiwa, kepribadian, budi pekerti, perilaku, personalitas, sifat, tabiat, temperamen, watak". Adapun berkarakter, adalah berkepribadian, berperilaku, bersifat, dan berwatak (Aeni, 2014: 50).

Sedangkan Imam Al-Ghazali menganggap karakter lebih dekat kepada akhlak, yaitu spontanitas manusia dalam bersikap, atau melakukan perbuatan yang telah menyatu dalam diri manusia sehingga ketika muncul tidak perlu dipikirkan lagi (Aeni, 2014: 50). Jadi dapat disimpulkan bahwa karakter merupakan suatu sikap atau watak yang sudah menjadi bawaan atau sudah menjadi ciri khas dari seorang induvidu, sehingga seseorang tersebut terdorong bertindak, besikap dan merespons sesuatu.

Masuk kepada religius, religiusi berasal dari bahasa asing yaitu religion yang memiliki arti agama (Huda, 2019: 20). Sedangkan menurut James Martineau agama adalah kepercayaan kepada tuhan yang selalu hidup. Yakni kepada jiwa dan kehendak ilahi yang mengatur alam semesta dan mempunyai hubungan moral dengan umat manusia (Shaleh \& Wisnaeni, 2019: 241).

Menurut Jalaluddin dalam bukunya "Psikologi Agama", agama yaitu meyakini adanya tuhan sebagai penguasa yang diatas dan disembah sebagai pencipta dan pemelihara alam semesta, ekspresi dari kepercayaan ini berupa ibadah, dan suatu keadaan jiwa yang mencerminkan kecintaani atau kepercayaani kepada Tuhan, bertindak, sikap dan perilakunyai sesuai dengan perintah Tuhan yang nampak atau diaplikasikan dalam kehidupan sehari-hari (Huda, 2019: 20).

Dari penyampaian di atas diketahui bahwa relegius yaitu sikap atau tingkah laku yang ada dalam diri sebagai sistem kepercayaan yang tertanam dalam diri seorang induvidu untuk menjalankan perintah- perintah agama dan mengaplikasikannya dalam kehidupan sehari- hari sebagai bentuk ketaqwaan kepada Allah SWT. Maka dapat disimpulkan bahwa penanaman karakter religius merupakan suatu bentuk penanaman karakter kepada seseorang induvidu yang mengacu kepada ajaran agama menjalankan perintah dan meninggalkan larangannya. Dan menjadikan agama 
sebagai panutan dalam bersikap dan bertindak dalam kehidupan sehari- hari (Huda, 2019: 20-21).

Menurut Sahlan karakteristik religius yang ada pada diri induvidu tampak pada: (1) sifat jujur, (2) adil, (3) menebar manfaat, (4) rendah hati, (5) bertanggung jawab, (6) visi kedepan, (7) disiplin. Salah satu ciri karakter religius menurut Sahlan tersebut adalah bermanfaat bagi orang lain (Markhamah et al., 2020: 103). Sedangkan menurut Muchlas Samani dan Harianto yang dapat dikatan cara bersikap yang berkaitan dengan Tuhan seperti, beriman dan bertakwa, jujur, disiplin, sabar, tawakal, ikhlas, amanah, menjaga diri, ringan tangan, pengabdian, bersyukur dan beradab (Samani \& Hariyanto, 2013: 49).

Dari paparan di atas maka nilai- nilai karakter religius selalu mengarah kepada apa yang selalu diperintahkan dalam agama (islam). Yaitu dengan besikap serta bertindak sesuai dengan pokok ajaran islam. Dimana yang menjadi dasar acuan karakter religius diantaranya ialah keteladanan rasulullah dan menjelma dalam sikap dan perilaku sehari-hari beliau yaitu, ash-shiddiq (cerdas), al-amanah (dapat dipercaya), at-tabligh (menyampaikan), al-fathanah (cerdaik serta bijaksana) (Musyirifin, 2020: 155-156). Berdasarakan penjelasan ini, bahwa nilai karakter religius yang baik adalah dibangun dengan sikap jujur dan bertanggung jawab, tidak berbohong, mencuri dan menipu, beriman dan bertakwa, menepati janji dan dapat di percaya, serta setia kepada keluarga, teman dan Negara.

Pencak silat termasuk salah satu olahraga beladiri yang mempunyai keterkaitan kebudayaan kesenian dan mental spiritual. Unsur ajaran pencak silat yaitu mampu mengembangkan prilaku dan watak individu yang berbudi luhur. (Gristyutawati, Purwono, \& Widodo) menjelaskan bahwa budi pekerti luhur merupakan dasar nilainilai norma kebudayaan masyarakat yang menjadikan pencak silat sebagai warisan bangsa indonesia. Dan Mulyana, menjelaskan bahwa kepribadian jati diri bangsa Indonesia terbentuk melalui cerminan ajaran-ajaran kebudayaan masyarakat yang mampu melahirkan dan menciptakan nilai luhur kualitas karakter pencak silat (Nandana et al., 2020: 24).

Sedangkan Purbodjati, menjelaskan bahwa pencak silat merupakan upaya pembangunan fisik, mental terhadap aspek mental spiritual dalam pengembangan individu dengan menanamkan nilai-nilai kebudayaan dengan tujuan membentuk kualitas jati diri yang berkepribadian bangsa (Nandana et al., 2020: 24). Jadi dapat di ketahui pencak silat adalah seni belai diri yang di warisankan oleh nenek moyang bangsa Indonesia secara turun temurun yang didalamnya terdapat unsur seni dan spiritual yang harus dijaga dan dilestarikan sebagai warisan budaya dan identitas bangsa Indonesia.

Nilai-nilai luhur pencak silat dapat digolongkan menjadi 4 aspek di antaranya ada aspek mental spiritual, aspek olahraga, aspek seni budaya dan aspek bela diri. Pada aspek mental spiritual, pencak silat dapat membangun serta menumbuhkan kepribadian dan karakter mulia seorang induvidu. Pada zaman sekarang untuk mengembangkan aspek spiritual dalam pencak silat yang harus diajarkan yaitu pada pengembangan aspek mental. Diantara aspek mental yaitu, bertakwa kepada Tuhan Yang Maha Esa dan berbudi luhur, percaya diri, tenggang rasa dan disiplin, persaudaraan, pengendalian diri dan tanggung jawab sosial. Pada aspek seni, seorang pesilat diharapkan mempunyai keterampilan gerak yang serasi serta menarik. Pencak 
Afif Putra Nazwan, Alfurqan: Nilai- Nilai Karakter Religius Dalam Kegiatan Pencak Silat...

silat sebagai budaya bangsa Indonesia yang mencerminkan identitas bangsa, memperkokoh rasa nasionalisme, memperkuat persatuan serta kepribadian bangsa. Dan mampu menyaring pengaruh budaya luar yang negatif serta dapat mengambil hal yang positif untuk pembaharuan yang membangun (Nur kholish, 2016: 79-81). Aspek olahraga memiliki keterampil dalam gerakan sangat efektif untuk menjamin kesehatan jasmani dan rohani yang dilandasi hasrat hidup sehat, ini berarti pesilat mempunyai kesadaran untuk latihan dengan sungguh-sungguh, semangat dalam mencari prestasi bila ada kejuraan dan menjunjung tinggi sportifitas (Huda, 2019: 37). Terakhir yaitu aspek bela diri, seorang pesilat mesti memiliki keterampil dalam melakukan gerakan, memiliki fisik serta mental yang kuat, sikap seorang pendekar, cepat tanggap serta mampu dalam mengendalikan diri (Nur kholish, 2016: 79-81). Dari keempat aspek tersebut merupakan nilai-nilai luhur yang terdapat dalam pencak silat, dimana nilai- nilai yang terdapat dalam pencak silat tersebut adalah pembentuk karakter, terutama pada pembentukan karakter religius, dan terkhusus terdapat pada aspek mental spiritual.

\section{Metode}

Pada penelitian ini peneliti menggunakan jenis penelitian lapangan (field research) dengan pendekatan kualitatif, pendekatan kualitatif yaitu suatu metode penelitian yang dipakai untuk meneliti pada kondisi objek yang alamiah, dimana peneliti merupakan instrumen kunci. Alasan peneliti mengambil jenis penelitian ini adalah agar data yang peneliti dapat secara observasi dilapangan merupakan data yang aktual atau data yang benar terjadi dan dapat dipertanggung jawabkan. Peneliti berusaha untuk memaparkan atau menggambarkan data tentang nilai- nilai karakter religius dalam kegiatan pencak silat ISMD Putra Setia Nagari Sikabu. Dalam penelitian ini yang menjadi narasumber atau informan adalah 2 orang guru atau pelatih dan 4 orang murid anggota perguruan ISMD Putra Setia. Pengumpulan data pada penelitian ini menggunakan observasi, wawancara dan dokumentasi.

\section{Hasil dan Pembahasan}

Dari hasil pengumpulan data yang telah peneliti lakukan dengan menggunakan metode wawancara, observasi, dan dokumentasi di perguruan ISMD Putra Setia Nagari Sikabu, penelitian ini memperoleh data tentang nilai- nilai karakter religius dalam kegiatan pencak silat ISMD Putra Setia Nagari Sikabu. Dalam penyajian data ini, peneliti mencoba menggambarkan nilai- nilai karakter religius melalui kegiatan pencak silat ISMD Putra Setia Nagari Sikab. Maka peneliti menyajikan data sebagai berikuti: 
1. Berdo'a sebelum latihan

Berdasarkan hasil wawancara pada tanggal 30 agustus 2021 dengan guru atau pelatih ISMD Putra Setia Nagari Sikabu, bapak Ardison mengatakan:

"sebelum melakukan latihan, para murid secara bersama- sama yang bapak pimpin sendiri untuk berdo'a bersama, supanya diberi kelancaran dalam latihan. Ketika sesudah latihan kami membaca hamdalah dan salawat nabi"

Hasil wawancara dapat disimpulkan bahwa sebelum melakukan latihan, mereka memulainya dengan berdo'a supaya diberi kelancaran dalam melakukan latihan dan sesudah melakukan latihan mereka secara bersama- sama mengucap Alhamdulillah sebagai bentuk syukur atas kelancaran latihan.

B. Tradisi berjabat

Pada perguruan Ikatan Seni Membela Diri (ISMD) Putra Setia, para anggotanya selalu berjabat tangan ketika bertemu di tempat latihan dan selalu menyalami guru ketika datang (observasi tanggal 25 agustus 2021). Berdasarkan wawancara pada tanggal 30 agustus 2021 dengan bapak Ardison selaku guru atau pelatih ISMD Putra Setia, mengatakan:

"Disini para murid dibiasakan menyapa dan berjabat tangan ketika bertemu, baik dalam latihan maupun diluar latihan, baik sesama murid maupun dengan gurunya yaitu apak dan etek"

Berdasarkan hasil observasi dan wawancara di atas bahwa tradisi berjabat tangan atau bersalaman sudah menjadik kebiasaan di perguruan ISMD Putra Setia. Berjabat tangan atau bersalaman dilakukan sesama murid, baik murid sesama murid maupun murid dengan guru atau pelatih. Tidak hanya ketikan latihan, mereka juga melakukan tradisi berjabat tangan atau bersalaman dimanapun dan kapanpun bertemu. Tujuan dari kebiasaan ini adalah agar merekatkan hubungan persaudaraan antara murid dengan murid maupun murid dengan guru atau pelatih.

\section{Adab dan sopan santun}

Pada perguruan Ikatan Seni Membela Diri Putra Setia Nagari Sikabu, para anggota atau muridnya sangat sopan ketika berbicara kepada gurunya dan menghormati yang senior (observasi tanggal 25 agustus 2021). Berdasarkan hasil wawancara tanggal 1 september 2021 dengan buk yeni selaku guru atau pelatih ISMD Putra Setia Nagari Sikabu, mengatakan: "Etek sebagai guru disini selalu memberikan nasehat kepada murid- murid etek ko supayo jan malawan kepado urang tuo, patuhi urang tuo dan hargai urang yang labiah gadang”.

Hal ini juga disampaikan oleh murid, yaitu hasil wawancara pada tanggal 3 september 2021, Sindi mengatakan: "Kami diajarkan untuk sopan santun kepada orang tua maupun kepada orang lain" Dan hal ini juga disampaikan oleh salah seorang murid yang bernama Riko, beliau mengatakan: "Kami dibimbing untuk selalu taat kepada orang tua dan agama, dan juga di ajarkan untuk selalu menjaga silaturahmi sesama anggota". Wawancara juga dengan murid lainnya yang bernama Sukma, beliau mengatakan: "Selain latihan fisik, guru mengajarkan kepada kami sikap sopan santun dan menghormati sesama bang" 
Afif Putra Nazwan, Alfurqan: Nilai- Nilai Karakter Religius Dalam Kegiatan Pencak Silat...

Berdasarkan hasil observasi dan wawancara di atas maka dapat peneliti simpulkan bahwa Pembentukan adap dan sopan santun merupakan salah satu tujuan dari ISMD Putra Setia. Penanaman ini dilakukan dengan cara pembiasaan ketika latihan. Selama kegiatan latihan murid dibiasakan untuk berbicara lembut dan sopan kepada pelatih, hal ini bertujuan supaya mereka dapat menghormati orang yang lebih tua. Dengan adanya pembiasaan tersebut diharapkan para murid dapat menghormati oran yang lebih tua di luar kegiatan latihan, khusunya kepada orang tua dan guru mereka.

\section{Pemberian nasehat}

Berdasarkan hasil wawancara dengan buk yeni, beliau mengatakan: "Etek sering bilang kepada murid- murid etek supanyo jan sombong dan jan menyalahgunakan apo yang dipelajari, jangan meninggalkan ibadah wajib, kalau dapat ibadah sunat jangan ditinggalkan. Kadang etek selalu berpesan seperti itu kepada murid- murid etek".

Berdasarkan wawancara tersebut maka dapat disimpulkan bahwa Pemberian nasehat diberikan agar murid bisa membentengi dirinya dari rasa ego karena bisa beladiri di khawatikan digunakan untuk hal yang keliru. Guru atau pelatih selalu memberikan nasehat- nasehat agar para murid menjadi manusia yang berbudi luhur tahu benar dan salah serta bertakwa kepada Tuhan Yang Maha Esa. Pemberian nasehat ini dilakukan oleh pelatih kepada murid ketika selesai latihan atau ketikan duduk dan berkumpul bersama.

\section{Latihan rutin}

Berdasarkan hasil wawancara tanggal 1 september 2021 dengan bapak Ardison, beliau mengatakan: "Kami disini melakukan kegiatan latihan 2 kali seminggu, yaitu pada malam kamis dan malam minggu. Selain basilek ini baik untuk fisik mereka, latihat basilek juga baik untuk melatih kesabaran dan ketekunan"

Dan peneliti juga melakukan wawancara dengan beberapa murid, yaitu tentang apa yang mereka rasakan setelah melakukan latihan silat pada perguruan Ikatan Seni Membela Diri (ISMD) Putra Setia Nagari Siabu. Berdasarkan hasil wawancara dengan murid pada tanggal 3 september 2021, Sukma mengatakan: "Tentunya badan terasa lebih sehat karena latihan fisik bang, dan juga diajarkan untuk lebih fokus, seperti fokus pada aba- aba latihan, seperti itulah bang" Juga disampaikan oleh salah seorang murid atas nama Rendi, beliau mengatakan: "Setelah saya mengikuti latihan, saya merasa badan saya lebih sehat dan rasa persaudaraan dan perkawanan saya lebih baik".

Berdasarkan hasil wawancara di atas maka dapat peneliti simpulkan bahwa kegiatan latihan dilakukan dua kali seminggu, yaitu pada malam kamis dan malam minggu. Adapun manfaat latihan pencak silat sangat baik sekali untuk fisik serta bisa melatih kesabaran, ketekunan bahkan melatih lebih fokus dan menambah teman.

\section{Pemberian hukuman}

Berdasarkan wawancara pada tanggal 1 september 2021 dengan bapak Ardison, beliau mengatakan: "Pemberian bentuk hukuman ini diberikan agar para murid 
lebih disiplin dalam latihan, seperti push up dan sit up, kalau terlambat atau melakukan kesalahan dalam latihan"

Dari hasil wawancara di atas maka pemberian hukuman dimaksud agar para murid menjadi orang yang disiplin dan bertanggung jawab, seperti pemberian push up ataupun sit up kepada murid yang terlambat atau keliru dalam melakukan gerakan. dan dalam pemberian hukuman guru atau pelatih tidak membedabedakan muridnya, bagi yang terlambat atau melakukan kesalah tetap diberi hukuman yang sama tanpa ada membedakan antara murid yang satu dengan yang lainnya.

Berdasarkan penelitian yang telah peneliti lakukan, ditemukan beberapa nilainilai karakter religius dalam kegiatan pencak silat ISMD Putra Setia Nagari Sikabu sebagai berikut: Pertma, Disiplin. Sikap ini tertanam pada murid perguruan ISMD Putra Setia Nagari Sikabu melalui kegiatan berdo'a sebelum dan sesudah latihan serta pada pemberian punishment atau hukuman. Sebelum latihan mereka mengawalinya dengan berdo'a yang dipimpin oleh pelatih dalam keadaan berbaris yang rapi, dan bagi yang terlambat akan diberi hukuman seperti push up dan sit up. Sehingga dengan kebiasaan ini menjadikan murid terbiasa dan disiplin memulai latihan dengan berdo'a dan datang tepat waktu ketika latihan.

Kedua, Jujur. Pada perguruan ISMD Putra Setia penanaman sikap jujur yaitu pada pemberian punishment kepada muridnya. Bagi murid yang terlambat atau melakukan kekeliruan dalam latihan, maka akan diberi hukuman seperti push up ataupun sit up maka disini murid dituntut untuk jujur ketika melakukan kesalahan, dan siap diberi hukuman seperti melakukan gerakan push up atau sit up sesuai arahan pelatih.

Ketiga, Sopan santun. Sikap ini sudah terlihat dari cara mereka terbiasa berbicara halus dan sopan kepada guru atau pelatih, dengan kebiasaan diharapkan juga terbawa keluar latihan, sehingga mereka bisa menjadi orang yang bisa menghormati orang lain terutama kepada orang tua dan guru.

Keempat, Sikap sabar. Di dalam dunia pencak silat yang terpenting adalah bagaimana cara seseorang bisa mengendalikan diri, yaitu dengan melatih kesabaran. Didalam kegiatan latihan ISMD Putra Setia sikap ini sudah tampak pada kegiatan latihan, dimana murid dilatih bersabar dalam menjalankan latihan, sabar dalam menghafal jurus- jurus dan gerakan sampai hafal dan mahir dalam melakukan gerakan silat.

Kelima, Tanggung jawab. Dalam kegiatannya pencak silat ISMD Putra Setia Nagari Sikabu, penanaman sikap tanggung jawab ini ditanamkan melalui latihan rutin, dimana murid bertanggung jawab menyelesaikaan latihannya. Sedangkan pelatih juga bertanggung jawab dalam melatih, mendidik, serta menjadi contoh yang baik bagi muridnya baik didalam latihan maupun diluar latihan.

Keenam, Kerja keras. Sikap kerja keras ditanamkan pada setiap latihan rutin, dimana murid harus mengerjakan tugasnya dengan berlatih sebaik-baiknya. Murid harus berlatih dengan sungguh- sungguh, mempelajari gerakan dengan baik, serta, serta mematuhi setiap instruksi dari pelatih, sehingga bisa menjadi pendekar yang baik.

\section{Simpulan}


Afif Putra Nazwan Alfurqan: Nilai- Nilai Karakter Religius Dalam Kegiatan Pencak Silat...

Berdasarkan dari hasil penelitian yang peneliti lakukan tentang nilai- nilai karakter religius melalui kegiatan pencak silat pada anggota perguruan ISMD Putra Setia Nagari Sikabu tahun 2021, maka dapat peneliti simpulkan sebagai berikut. Adanya ditemukan nilai- nilai karakter religius dalam kegiataan pencak silat pada anggota perguruan ISMD Putra Setia Nagari Sikabu, antara lain: 1) adanya sikap disiplin, 2) adanya sikap jujur, 3) adanya sikap sopan santun, 4) adanya sikap sabar, 5) adanya sikap tanggung jawab, dan 6) adanya sikap kerja keras.

\section{Referensi}

Adyanto, S. P., Muhajir, \& Fajriyah, K. (2018). Karakteristik Siswa Anggota Ekstrakulikuler Pencak Silat Di Tinjau Dari Nilai Karakter. Jurnal Sinektik, $1(1), 46-52$.

Aeni, A. N. (2014). Pendidikan Karakter Untuk Siswa SD Dalam Perspektif Islam. Mimbar Sekolah Dasar, 1(1), 50-58.

Ainissyifa, H. (2014). Pendidikan Karakter Dalam Perspektif Pendidikan Islam. Jurnal Pendidikan Universitas Garut, 8(1), 1-26.

Huda, M. N. (2019). Pembentukan Karakter Religius Melalui Pendidikan Pencak Silat (Studi Multi Kasus Persaudaraan Setia Hati Terate di SMP Bahrul Ulum Putat Jaya dan Pagar Nusa di SMP KHM. Nur Karang Tembok) Surabaya. Universitas Islam Negeri Sunan Ampel.

Markhamah, Imron, A., Sabardila, A., \& Rustini. (2020). Reaktulisasi Pendidikan Karakter Berbasis AL- Qur'an. Surakarta: Muhammadiyah University Press.

Ma'ruf, A. (2019). Penanaman Karakter Religius Di Madrasah Aliyah Tahfizul Qur'an Istiqomah Sambas Purbalingga. IAIN Purwokerto.

Musyirifin, Z. (2020). Implementasi Sifat-Sifat Rasulullah Dalam Konseling Behavioral. Al - Irsyad : Jurnal Bimbingan Konseling Islam, 11(2), 151-159.

Nandana, D. D., Maksum, A., \& Priambodo, A. (2020). Pengaruh Latihan Pencak Silat Terhadap Pembentukan Konsep Diri Dan Kepercayaan Diri Siswa. Multilateral Jurnal Pendidikan Jasmani dan Olahraga, 19(1), 23-31.

Novita sari, L., Fita Asri Untari, M., \& Ardiyanto, A. (2020). Penanaman Karakter Disiplin Melalui Ekstrakurikuler Pencak Silat Di SD Muhammadiyah 11 Semarang. JournaL Of Primary And Children's Education, 3(2), 16-23.

Nur kholish, M. (2016). Aplikasi Nilai-Nilai Luhur Pencak Silat Sarana Membentuk Moralitas Bangsa. Jurnal Sportif, 2(2), 76-84.

Samani, M., \& Hariyanto. (2013). Konsep Dan Model Pendidikan Karakter. Bandung: PT Remaja Rosdakarya.

Shaleh, A. I., \& Wisnaeni, F. (2019). Hubungan Agama Dan Negara Menurut Pancasila Dan Undang-Undang Dasar Negara Republik Indonesia Tahun 1945. Jurnal Pembangunan Hukum Indonesia, 1(2), 237-249.

Yuliawan, D. (2016). Pembentukan Karakter Anak Dengan Jiwa Sportif Melalui Pendidikan Jasmani Olahraga dan Kesehatan. Jurnal Sportif, 2(1), 101-112. 